Tamara Rajić ${ }^{1}$

Ivan Nikolić ${ }^{2}$

Isidora Milošević ${ }^{3}$
JEL: M31, C51

DOI: $10.5937 /$ industrija45-16080

UDC:

Original Scientific Paper

\title{
Antecedents and outcomes of retailer reputation: Evidence from an emerging economy ${ }^{4}$
}

Article history:

Received: 28 August 2017

Sent for revision: 12 September 2017

Received in revised form: 15 November 2017

Accepted: 15 November 2017

Available online: 25 December 2017

\begin{abstract}
Over prevous years the construct of corporate reputation has received much attention among academics and business practitioners. Whereas researchers' interests have been mainly pointed to the implications of good corporate reputation, its antecedents have largly been understudied. Moreover, majority of previous research took part in the context of the U.S. and Western Europe, leaving service industries in emerging economies rather neglected area. Hoping to fill this void in marketing knowledge, the objective of this study is to propose and empirically examine a model of retailer reputation, by incorporating the construct into the framework of established relationships among key service evaluation constructs. Conceptual model has been examined on a sample of Serbian grocery retail customers by means of structural equation modelling (SEM). Results of the study point to significant effect of service quality and value on retailer reputation and the direct impact of reputation on customer loyalty. Limitations of the study have been discussed and directions for future research are provided.
\end{abstract}

Keywords: corporate reputation, service quality, perceived value, customer loyalty, retailing, Serbia

\footnotetext{
${ }^{1}$ Economics Institite, Serbia, tamara.rajic@ecinst.org.rs

${ }^{2}$ Economics Institite, Serbia

${ }^{3}$ University of Belgrade, Technical faculty in Bor

4 This paper is a part of research project no. 179001 financed by the Ministry of Education, Science and Technological Development of The Republic of Serbia
} 
Rajić T. et al.: Antecedents and outcomes of retailer reputation: Evidence from an...

\section{Determinante i efekti reputacije maloprodavca: Rezultati iz privrede u razvoju}

Apstrakt: Koncept korporativna reputacija predmet je značajne pažnje u akademskim i poslovnim krugovima poslednjih godina. Pažnja istraživača uglavnom je fokusirana na implikacije dobre korporativne reputacije, dok su njene determinante ostale mahom neistražene. Većina prethodnih istraživanja realizovana je na teritoriji SAD-a i Zapadne Evrope, dok su uslužne delatnosti u zemljama u razvoju do sada nedovoljno istražene. U nameri da se popuni pomenuti gep u marketinškoj literaturi, cilj ovog istraživanje je predložiti $i$ empirijski ispitati model reputacije maloprodavca, uključivanjem pomenutog koncepta u okvir ustanovljenih veza među ključnim konceptima evaluacije usluga. Konceptualni model je testiran na uzorku korisnika usluga maloprodaje u Srbiji, sa dominantnim učešćem prehrambenog asortimana, primenom modelovanja pomoću strukturnih jednačina. Rezultati istraživanja ukazuju na značajan uticaj kvaliteta usluga i vrednosti na reputaciju maloprodavca i direktan uticaj reputacije na lojalnost potrošača. U radu su razmotrena ograničenja i navedene smernice za dalja istraživanja.

Ključne reči: korporativna reputacija, kvalitet usluga, percipirana vrednost, lojalnost potrošača, maloprodaja, Srbija

\section{Introduction}

Over previous years, the construct of corporate reputation has been the subject of considerable attention among academics and business practitioners. Effective management of reputation can yield a myriad of benefits. Empirical studies have reported a strong impact of good corporate reputation on employees' pride in being affiliated with the firm and job satisfaction (Helm, 2011), customers' willingness to pay price premium for good corporate reputation (Graham \& Bansal, 2007) and its positive influence on the market value of a company (Dowling, 2006; Fernández-Gámez et al., 2016; Wang et al., 2016). Good reputation attracts valuable employees, investors and business partners and can protect the company from failure in times of crisis (Jarvinen \& Suomi, 2011; Gatzert, 2015). Strong reputation facilitates the introduction of a new product and acts as a formidable barrier to market entry (Keh \& Xie, 2009). It has been widely acknowledged that good reputation positively affects company's financial performance (Caruana et al., 2005; Dowling, 2006; Fernández-Gámez et al., 2016). Good reputation makes it less likely that suppliers will demand payment in advance and helps companies gain access to new markets through established distributors (Dowling, 2006). 
Rajić T. et al.: Antecedents and outcomes of retailer reputation: Evidence from an...

A significant body of literature on corporate reputation has been dominated by the implications of favourable reputation, whereas the examinations of structural models incorporating the antecedents and outcomes of corporate reputation have generally been scarce. Majority of previous studies on corporate reputation took place in the U.S. and Western Europe, while little empirical research on the subject has been conducted in the context of a developing economy. Corporate reputation has been mainly studied taking the perspective of employees, managers or investors (Caruana et al., 2005; Helm, 2011; Jarvinen \& Suomi, 2011). Surprisingly, there is a scarcity of research on corporate reputation from the perspective of companies' prime generators of revenue, namely customers (Walsh et al., 2006; Graham \& Bansal, 2007). Therefore this study aims to bridge the gaps in the corporate reputation literature by incorporating the construct into the framework of established relationships among customer behavioural intentions and its widely acknowledged antecedents, service quality and perceived value, in thus far scarcely examined context of a developing economy. The study has been performed in a grocery retail setting in Serbia, as corporate reputation becomes particularly important in competitive markets (Walker, 2010), and this service industry has been exposed to rising competitive pressures over previous years and the trend is expected to hold into the future (Rajic \& Dado, 2013).

The remainder of this paper is organized as follows. The next section describes conceptual framework and proposes research hypotheses. This is followed by the explanation of the methodology applied in this study. Results are presented subsequently, followed by the discussion of the main implications. Some notice has been given to the limitations of the study and directions for future research have been proposed.

\section{Conceptual background and research hypotheses}

\subsection{Corporate reputation and customer loyalty}

Corporate reputation is considered as one of the most important intangible assets and the main source of company's sustainable competitive advantage (Walker, 2010; Jarvinen \& Suomi, 2011), as its intangible essence makes it impossible for competing firms to replicate good reputation, at least in the short term (Keh \& Xie, 2009). Despite rising interest in corporate reputation, there is no commonly agreed upon definition of the construct. Literature on corporate reputation describes the construct as: (i) „a collective assessment of a company's ability to provide valued outcomes to a representative group of stakeholders" (Fombrun et al., 2000, p. 243), (ii) a collective judgment of a company based on the assessment of its financial, social and environmental 
Rajić T. et al.: Antecedents and outcomes of retailer reputation: Evidence from an...

impacts over time (Ewing et al., 2010), (iii) a stakeholder's overall evaluation of a company over time which is based on his/her direct experiences with the company and/or information about the company's actions or its comparison with competitors (Gotsi \& Wilson, 2001). It has been argued that different stakeholders consider diverse issues in evaluating corporate reputation (Caruana et al., 2005) and that a company may have different reputations depending on the issue that is being considered, such as profitability, social and environmental responsibility, etc. (Walker, 2010). However there is little disagreement that it takes time to build good reputation and that favourable reputation is vital for long term survival of a company. According to Vuković et al. (2016, p. 161) "good corporate reputation results in the establishment of mutual trust with consumers and consequently stimulates sales". Strong corporate reputation is of even higher relevance for service companies in comparison with manufacturers, especially those offering services rich in credence attributes and whose quality is difficult for customers to assess even after consumption, whereupon good corporate reputation acts as a service quality guarantee (Sarstedt et al., 2012). Some empirical findings indicate positive impact of corporate reputation on customer citizenship behaviour, i.e. customers' willingness to help other shoppers use the service correctly and provide helpful feedback to customer service (Bartikowski \& Walsh, 2011).

Previous studies provide evidence of positive impact of corporate reputation on customers' perceptions of reliability and integrity of the exchange partner, which are necessary prerequisites to building good customer relations (Keh \& Xie, 2009; Park et al., 2012), which in retail environment strongly impact customer loyalty (Vesel \& Zabkar, 2010). Building a loyal customer base is expected to positively affect company's bottom line, as it is less costly to serve loyal customers than acquire new ones, loyal customers are more likely to buy additional services, pay higher prices to maintain valuable relationships with service provider and spread positive word-of-mouth (Zeithaml et al., 1996). Nurturing customer loyalty is particularly important for grocery retailers operating in highly competitive retail arena due to multitude of distribution channels at customers' disposal and minimal switching costs (Martinelli \& Balboni, 2012). Review of literature indicates that in the context of retailing a serious impediment towards higher levels of customer loyalty, from an operational perspective, are out-of-stock situations (Grubor \& Milićević, 2016).

According to Oliver (1999) the development of customer loyalty is a sequential process. Customers first become loyal in a cognitive sense, which is based on information about a product or service, and only after cumulatively satisfying usage occasions does he/she develop affective loyalty, based on liking of the product or service experience. The following phase is conative loyalty, i.e. behavioural intentions stage, which relates to strongly held commitment to rebuy preferred product or service, which is expected to evolve into action loyalty, i.e. readiness to act. Although companies' financial statements are 
Rajić T. et al.: Antecedents and outcomes of retailer reputation: Evidence from an...

affected by action loyalty, the measurement of action loyalty is arduous in practice. Therefore, majority of researchers employ customer behavioural intentions, i.e. willingness to repatronize and recommend a company, as a proxy for action loyalty (Chen \& Chen, 2010; Pan et al., 2012). Bartikowski and Walsh (2011) in a multi-industry study, involving retail customers, provide evidence of significant impact of corporate reputation on customer loyalty. These findings have been also supported by some other empirical results from the context of traditional and online services (Nguyen \& Leblanc, 2001; Caruana \& Ewing, 2010; Bartikowski et al., 2011; Ko et al., 2013). On the basis of aforementioned findings the following hypothesis is proposed:

$\mathrm{H1}$ : Retailer reputation positively affects customer loyalty.

\subsection{Retail service quality}

Service quality is widely regarded as one of the most explored issues in the field of Services Marketing. The surge of interest in service quality started in the late 1980s when Parasuraman et al. (1988) proposed SERVQUAL scale, 22 -item instrument for assessing customer perceptions of service quality. The authors defined service quality as 'the customer's judgment about an entity's overall excellence or superiority' (Parasuraman et al., 1988, p. 15) which should be measured as the degree and direction of the difference between customer's perceptions and expectations of the service provision. SERVQUAL scale was intended to be applicable across a wide range of services and as such was eagerly adopted by a vast number of researchers and has continued to attract scholarly attention to date (Setó-Pamies, 2012).

However it has also been much criticised over the years, especially on the grounds of using difference scores and failure of its numerous applications to support five-dimensional structure of service quality across service industries (cf. Asubonteng et al., 1996; Buttle, 1996). The application of the SERVQUAL scale in retail context resulted in the conclusion that the instrument does not adequately tap into service quality construct in retailing and that it should be refined taking into account specificities of service provision in retailing (Dabholkar et al., 1996). On the grounds of the aforementioned arguments Dabholkar et al. (1996) proposed Retail Service Quality Scale (RSQS) which has later on provided a basic framework for service quality measurement across retail formats and economic and national contexts (Nadiri \& Tümer, 2009; Martinelli \& Balboni, 2012).

Marketing literature has frequently suggested that measurement instruments developed in one service and cultural context should not be directly transposed to diverse settings (Bartikowski \& Walsh, 2011; Martinelli \& Balboni, 2012). Therefore this study focuses on the measurement of retail service quality on the basis of attributes deemed most important to Serbian 
Rajić T. et al.: Antecedents and outcomes of retailer reputation: Evidence from an...

grocery shoppers. The construct of service quality has evoked much interest among researchers due to its expected positive impact on customer loyalty. In a multi-industry study Zeithaml et al. (1996) provide evidence of significant influence of service quality on customer behavioural intentions. These findings have been later on supported in a variety of service settings, including retailing (Nadiri \& Tümer, 2009; Žabkar et al., 2010; Martinelli \& Balboni, 2012). Studying the impact of corporate reputation on employees' awareness of their contribution to firm's reputation Helm (2011) emphasized the impact of product and service quality on reputation perceptions. Some recent findings from the context of e-retailing also suggest significance of service quality as a predictor of corporate reputation (Caruana \& Ewing, 2010; Park et al., 2012). Despite scant empirical support of the antecedent role of service quality to corporate reputation in the context of traditional retailing, the existence of positive association between these constructs is expected. Therefore, the following hypotheses are proposed:

H2: Retail service quality positively affects customer loyalty;

H3: Service quality positively affects retailer reputation.

\subsection{Perceived value}

Recent marketing literature has given much heed to the construct of perceived value due to its prospective impact on customer behaviour and consequently companies' financial performance. Early studies on customer value build upon pricing literature and take a stance of perceived value as a difference between benefits customer receive from an offer and monetary costs they incur to obtain a product or service (cf. Ruiz et al., 2008). Later on measuring customer value researchers have mainly employed Zeithaml's (1988) conceptualization of value according to which „value represents a trade-off of the salient give and get components" (p. 14), whereas give component of the equation in addition to monetary sacrifice includes time and effort expended. Underscoring the importance of value for gaining competitive edge Woodruff (1997) argues that „the issue does not seem to be whether an organization should compete on customer value delivery, but rather how it should do it“ (p. 140). Implicit in widely adopted conceptualization of perceived value is the notion of positive impact of service quality on value. Evidence in support of this link comes from a variety of service industries, including retailing (Brady et al., 2005; Chen \& Cheng, 2012; Pisnik Korda et al., 2012; Rajic et al., 2013). The challenge that practitioners face is delivery of notably valued offer, as „what constitutes value appears to be highly personal and idiosyncratic" (Zeithaml, 1988, p. 13). Significant direct effect of value on customer repurchase intentions has been supported in the context of grocery retailing (Ruiz et al., 2008). Several studies in the marketing literature have also indicated perceived value as the most influential driver of customer 
Rajić T. et al.: Antecedents and outcomes of retailer reputation: Evidence from an...

behavioural intentions (Kuo et al., 2009; Chen \& Cheng, 2012). Although there is a dearth of empirical evidence in support of the role of perceived value as an antecedent to retailer reputation, it would be worthwhile to examine this link, as literature review indicates that fair treatment of customers, in terms of prices companies charge and quality of goods and services they deliver, shapes customers' opinions of the companies (Page \& Fearn, 2005). The aforementioned arguments lead to the following hypotheses:

H4: Retail service quality has a positive impact on perceived value;

H5: Perceived value has a positive impact on customer loyalty;

H6: Perceived value positively influences retailer reputation.

Conceptual model which incorporates hypothesized relationships is presented in Figure 1.

Figure 1. Conceptual model

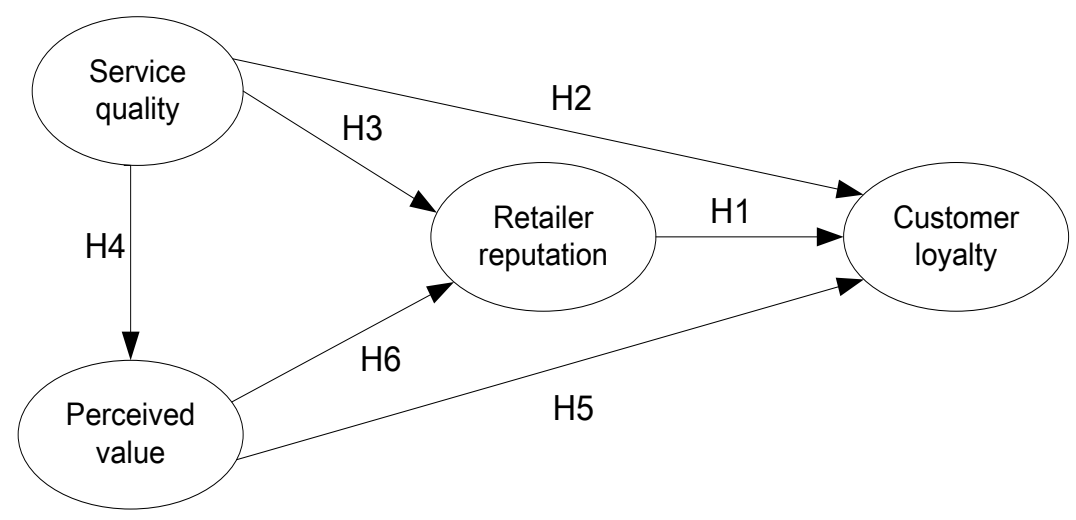

Source: authors'

\section{Methodology}

\section{1.}

Sample and measures

The study was conducted on a sample of grocery retail customers. Students of a small public faculty, attending Marketing and Management-related courses, who were previously trained for personal interviewing, participated in 
Rajić T. et al.: Antecedents and outcomes of retailer reputation: Evidence from an...

data collection. Fieldwork took place in the districts of Bor and Zajecar in Eastern Serbia region. Questionnaires were distributed to selected households whereupon persons mainly in charge for grocery shopping in their respective households were invited to participate in the study. Respondents' task was to rate the retailer with the highest proportion in their monthly expenses for groceries and related assortment. Out of 350 distributed questionnaires, 294 complete cases were collected, yielding a response rate of $84 \%$. Majority of respondents were females $(56.5 \%)$, aged between 25 and $44(56.3 \%)$ and educated up to secondary level (64.3\%).

Items used in this research were adapted from previous studies. As psychometrically sound service quality measurement instrument suitable to Serbian grocery retail context has not been developed heretofore, items addressing service quality construct have been proposed following Churchill's (1979) sequential procedure for developing multi-item measures of marketing constructs. Extensive literature review on service quality measurement, in particular retail service quality, was followed by several rounds of group discussion with grocery shoppers.

Focus group participants were asked to describe their notions of retail service quality and attributes that matter them most in evaluating quality of services offered by a retailer. To stimulate insightful comments respondents were also asked to try to recall and describe an incident which made some shopping trip rather inconvenient or made them feel pleased with the choice of retailer. Relevance of RSQS items (Dabholar et al., 1996) have also been discussed with participants in later stages of qualitative work. Quality attributes deemed important by majority of respondents were included in the questionnaire. Although items related to quality and freshness of goods are included in the RSQS scale, Serbian respondents do not consider these traits when making judgments of retail service quality, as fresh and quality products are perceived as commonly delivered among retailers. What really makes a difference between retail outlets, in the opinion of Serbian shoppers, is the width and depth of the assortment offered by various retailers. In addition to assortment, group discussion revealed that Serbian shoppers pay particular attention to employees' politeness, efficiency and readiness to respond to customer inquiries. In support of face validity of measures, final pool of items was discussed with experts from academia and first-line management of one of the leading European grocery retailer which operates in Serbia as well. Items addressing the construct of retail service quality are provided in the Appendix.

The construct of perceived value was operationalized using three items adapted from Brady et al. (2005) and Lai et al. (2009). Respondents' task was to stipulate the extent to which they agreed that the service they received from the chosen retailer was valuable, that the amount they paid was a reasonable price for the quality of goods and services they received from the retailer and 
Rajić T. et al.: Antecedents and outcomes of retailer reputation: Evidence from an...

the degree to which they agreed that the service quality they received from the retailer was worth their time, energy and efforts. Corporate reputation was assessed with five items, adapting three items from existing literature (Nguyen \& Leblanc, 2001) and adding two additinal statements to more thoroughly tap into the conceptual domain of the construct. Respondents were asked to indicate to what extent they agreed that the retailer has good reputation, better reputation than competitors, is reliable, trustworthy and socially responsible. Customer loyalty was measured with four items adapted from Brady et al. (2005) and Žabkar et al. (2010). Respondents' task was to indicate probability of using the same retailer again, recommending the retailer to friends and relatives, speaking highly of the retailer and doing most of the future household purchases at the same retailer. All items were measured on a 7-point Likert-type scale ranging from 1-strongly disagree to 7strongly agree. To eliminate any ambiguity in the questionnaire a pilot test was performed prior to a large scale survey.

\subsection{Analyses}

Exploratory factor analysis was performed first in order to uncover underlying dimensions of retail service quality construct. Composite scores were calculated on the basis of service quality dimensions and entered into the second stage of analysis upon which structural equation modelling, using maximum likelihood as the method of parameter estimation, was performed to estimate relationships among latent variables depicting conceptual model. Anderson and Gerbing's (1988) two-step procedure was adhered to in the examination of structural relationships, implying assessment of construct validity by means of confirmatory factor analysis (CFA), followed by the analysis of hypothesized relationships. Data analyses were performed using SPSS v.18 and LISREL 8.80 (Jöreskog \& Sörbom, 1993).

\section{Results}

\subsection{Factor analysis}

Dimensionality of service quality construct was examined in an iterative procedure. The procedure included several steps, as follows: 1) principal component analysis (PCA) with varimax rotation, 2) deletion of items loading .40 or above on more than one factor and repetition of factor analysis, 3) calculation of Cronbach's alpha values and item-to-total correlations and deletion of unreliable items. Factorability of the intercorrelation matrix was examined by inspecting Kaiser-Meyer-Olkin (KMO) measure of sampling adequacy and Bartlett's test of sphericity. KMO value of .907 and significance 
Rajić T. et al.: Antecedents and outcomes of retailer reputation: Evidence from an...

of Bartlett's test $\left(x^{2}{ }_{(190)}=2570.478, p<.001\right)$ indicated adequacy of data for factor analysis. Kaiser's rule of eigenvalues higher than 1 was selected as the criterion for factor extraction. Iterative procedure yielded four internally consistent dimensions of retail service quality which explained $61 \%$ of the variance in the sample. Cronbach's alpha values ranged from 0.752 to 0.873 and being higher than generally suggested threshold of 0.70 (Nunnally \& Bernstein, 1994) indicated acceptable reliability of service quality dimensions. Rotated component matrix is presented in the Appendix. On the basis on their content factors were named as follows: service personnel, communication, store layout and assortment, ambience.

\subsection{Measurement analysis}

Confirmatory factor analysis of the model comprising service quality, value, reputation and loyalty resulted in satisfactory fit of the measurement model. Although the analysis yielded statisticlly significant and thus unacceptable $x^{2}$ value $\left(X^{2}=211.032, d f=97, p<.001\right)$, due to its sensitivity to sample size the analysis was supplemented with other absolute and relative fit indices, in compliance with recommendations of Hair et al. (2010). Table 1 displays commonly used fit indices, their recommended values and results of this study.

Table 1. Recommended values of fit indices and results of measurement analysis

\begin{tabular}{l|l|l}
\hline Fit indices & $\begin{array}{l}\text { Recommended } \\
\text { values }\end{array}$ & Results \\
\hline$X^{2} / \mathrm{df}$ & $<3$ & 2.17 \\
GFI (Goodness-of-fit Index) & $>0.90$ & 0.92 \\
RMSEA (Root Mean Square Error of & $<0.08$ & 0.06 \\
Approximation) & & \\
SRMR (Standardized Root Mean Square & $<0.08$ & 0.06 \\
Residual) & & \\
CFI (Comparative Fit Index) & $>0.90$ & 0.96 \\
NFI (Normed Fit Index) & $>0.90$ & 0.94 \\
NNFI (Non-normed Fit Index) & $>0.90$ & 0.96 \\
\hline
\end{tabular}

Source: authors' calculations

As overall fit of the measurement model was supported, analysis proceeded with the examination of construct validity and reliability. Average variance extracted (AVE), which denotes the extent of variance explained by the construct in relation to the variance due to measurement error, was calculated. As presented in Table 2, all constructs, with the exception of service quality ( $\mathrm{VVE}=0.49$ ) had $\mathrm{AVE}$ values above the recommended cut-off value of 0.50 , which together with significant standardized factor loadings 
Rajić T. et al.: Antecedents and outcomes of retailer reputation: Evidence from an...

( $p<.001)$ ranging from 0.66 to 0.92 indicated acceptable convergent validity (Fornell \& Larcker, 1981). In support of convergent validity of the constructs, all composite reliability scores (CR) and Cronbach's alpha values were higher than the lower bound of 0.70 .

Table 2. Analysis of convergent validity

\begin{tabular}{lllllcl}
\hline Construct & Item & $\begin{array}{l}\text { Std.factor } \\
\text { loading }\end{array}$ & t-value & AVE & $\begin{array}{c}\text { Cronbach's } \\
\text { a }\end{array}$ & CR \\
\hline Retail & SQ1 & 0.68 & $9.90^{* *}$ & 0.49 & 0.79 & 0.80 \\
service & SQ2 & 0.66 & $9.59^{* *}$ & & & \\
quality & SQ3 & 0.78 & $11.06^{* *}$ & & & \\
& SQ4 & 0.69 & - & & & 0.85 \\
\hline Perceived & V1 & 0.88 & $16.58^{* *}$ & 0.66 & 0.84 & \\
value & V2 & 0.75 & $13.49^{* *}$ & & & \\
& V3 & 0.79 & - & & & \\
\hline Retailer & R1 & 0.86 & $16.62^{* *}$ & 0.59 & 0.88 & \\
reputation & R2 & 0.76 & $14.03^{* *}$ & & & \\
& R3 & 0.72 & $12.95^{\star *}$ & & & \\
& R4 & 0.71 & $12.76^{* *}$ & & & \\
& R5 & 0.79 & - & & & \\
\hline Customer & L1 & 0.82 & $15.18^{* *}$ & 0.74 & 0.92 & \\
loyalty & L2 & 0.91 & $17.29^{* *}$ & & & \\
& L3 & 0.92 & $17.49^{* *}$ & & & \\
& L4 & 0.78 & - & & &
\end{tabular}

Source: authors' calculations

Discriminant validity of the constructs was examined by comparing square roots of AVEs with correlations among the constructs, as presented in Table 3. Square root of AVE of each construct in a pair being higher than the correlation among the constructs provided evidence in support of discriminant validity (Fornell \& Larcker, 1981).

Table 3. Analysis of discriminant validity

\begin{tabular}{|l|l|l|l|l|}
\hline & Service quality & Value & Reputation & Loyalty \\
\hline Service quality & 0.70 & & & \\
\hline Value & $0.56^{\star *}$ & 0.81 & & \\
\hline Reputation & $0.64^{\star \star}$ & $0.73^{\star *}$ & 0.77 & \\
\hline Loyalty & $0.57^{\star *}$ & $0.77^{\star *}$ & $0.70^{\star *}$ & 0.86 \\
\hline
\end{tabular}

Note: Values on the diagonal are square roots of AVEs, values below the diagonal are correlations, ${ }^{* *}$ correlations are significant at $\mathrm{p}<.01$

Source: authors' calculations 
Rajić T. et al.: Antecedents and outcomes of retailer reputation: Evidence from an...

\subsection{Structural analysis}

Having established valid and reliable measurement model, analysis proceeded with the examination of structural model. Fit indices, such as $\mathrm{X}^{2} / \mathrm{df}$ (2.17), GFI (0.92), RMSEA (0.06), SRMR (0.06), NFI (0.94), NNFI (0.96), CFI (0.96) indicated acceptable fit of the structural model. Given the satisfactory fit of the model, hypothesized relationships were then examined. As predicted in Hypothesis 1, retailer reputation exerted significant positive influence on customer loyalty $(\beta=0.62, t=4.90)$. Support was not provided for Hypothesis 2 , implying the direct impact of service quality on customer loyalty $(\gamma=0.04$, $t=0.56)$. Service quality was positively related to retailer reputation $(\gamma=0.36$, $t=5.21)$ and perceived value $(y=0.66, t=8.37)$, thereby providing support for Hypotheses 3 and 4, respectively. As predicted in Hypothesis 5, customer loyalty was significantly influenced by perceived value $(\beta=0.36, t=3.73)$. Perceived value had a positive and significant effect on retailer reputation $(\beta=0.63, \mathrm{t}=8.76)$. Thus, Hypothesis 6 was supported. The results of hypothesis testing are presented in Table 4.

Table 4. The results of hypothesis testing

\begin{tabular}{llll}
\hline Hypotheses & $\begin{array}{l}\text { St. } \\
\text { estimate }\end{array}$ & t-value & Result \\
\hline H1: Retailer reputation $\rightarrow$ Customer loyalty & 0.62 & 4.90 & Supported \\
H2: Service quality $\rightarrow$ Customer loyalty & 0.04 & 0.56 & Not supported \\
H3: Service quality $\rightarrow$ Retailer reputation & 0.36 & 5.21 & Supported \\
H4: Service quality $\rightarrow$ Perceived value & 0.66 & 8.37 & Supported \\
H5: Perceived value $\rightarrow$ Customer loyalty & 0.36 & 3.73 & Supported \\
H6: Perceived value $\rightarrow$ Retailer reputation & 0.63 & 8.76 & Supported \\
\hline
\end{tabular}

Source: authors' calculations

Results of this study indicate significant direct effect of retailer reputation on customer loyalty and provide evidence in support of the antecedent roles of service quality and perceived value to retailer reputation. Besides reputation, value was also found to be a significant direct antecedent of loyalty, whereas the influence of service quality on customer loyalty was mediated via reputation and perceived value. Unlike total effect of retailer reputation on customer loyalty, which consists only of the direct effect, total effects of both service quality and value on customer loyalty include also indirect effects. Findings of this study indicate that in terms of total effect, value is the most significant determinant of customer loyalty (0.75), followed by service quality $(0.68)$ and retailer reputation (0.62). Proportions of explained variance in endogeneous variables, perceived value, retailer reputation and loyalty, amounting to $43.4 \%, 82.1 \%$ and $84.5 \%$ respectively, provide evidence in support of good explanatory power of the model. 
Rajić T. et al.: Antecedents and outcomes of retailer reputation: Evidence from an...

\section{Discussion}

\subsection{Theoretical and managerial implications}

Corporate reputation has been the subject of much scholarly research and practitioners' interest over recent years. However previous studies have been mainly conducted in developed economies and focused on implications of good corporate reputation, leaving the antecedents and consequences of reputation in a context of an emerging economy rather underresearched area. Hoping to fill this void in services marketing literature, the aim of this study was to propose and examine a model of retailer reputation in the context of a developing economy, by integrating reputation into the framework of established relationships among key service evaluation constructs. By providing evidence in support of the antecedent role of service quality and value to retailer reputation and its impact on customer loyalty this study enhances the body of scholarly knowledge. Findings of this study also bear managerial relevance. As indicated by the study, retailer reputation significantly drives customer willingness to spread positive word-of-mouth and repurchase from the same retailer in the future. Therefore particular attention should be paid to measurement and management of reputation, the more so in service industries deemed highly attractive to foreign competitors, as good reputation may play the role of market entry barrier. However retailers should not neglect provision of quality services and the delivery of benefits that surpass monetary and non-monetary sacrifice made to obtain the benefits. Although customers do not necessarily opt for the highest service quality, customers' behavioural intentions are determined indirectly by service quality, through the impact of quality on customer perceptions of reputation and perceived value. Findings of this study are in compliance with previous research which indicated importance of service personnel' behaviour and interaction with customers on quality perceptions of the latter (Nadiri \& Tümer, 2009). In order to enhance service quality and its positive consequences, retail managers are advised to invest in training programs of front-line personnel regarding customer relations. Due attention should be also paid to width and depth of assortment, layout and ambience of retail outlets. Results of this research are consistent with the findings of prior studies which indicated the most significant influence of perceived value on customer loyalty, in terms of total effect (Kuo et al., 2009; Chen \& Cheng, 2012). Not only does perceived value influence retailer reputation, but it is also an important direct driver of customer loyalty. Customers may differ in terms of priority they attach to diverse aspects of service and whereas some prefer lower prices others may find convenience more important. Therefore retail managers are advised to probe deeper into the construct of perceived value 
Rajić T. et al.: Antecedents and outcomes of retailer reputation: Evidence from an...

and segment customers accordingly so as to tailor and deliver service offer concordant to the benefits required by target groups of customers.

\subsection{Limitations and directions for future research}

This study has some limitations which may provide opportunities for future research. One of the main limitations is that the study was conducted on a convenience sample of retail customers. So future research would benefit from more randomized sampling. Another drawback of the study is its crosssectional design. In order to establish magnitude and direction of causality future studies should be based on longitudinal data. In respect to the direction of causality, future research should be also conducted in diverse service settings, all the more so as literature provides evidence of regarding reputation as a proxy to service quality in service settings rich in credence attributes. Therefore, it would be worthwhile to examine the direction of causality between service quality and reputation in high-risk and highinvolvement services.

Previous studies conducted in the context of developed economies indicate multifaceted nature of corporate reputation (Walsh \& Beatty, 2007). Therefore, retailers operating in the context of a developing economy are highly advised to examine more thoroughly the dimensionality of the construct of corporate reputation and relative importance of eventual dimensions as predictors of customer loyalty, measure them periodically and take corrective actions accordingly.

The proposed model of retailer reputation was not intended to be an allencompassing model. Clearly, there might be some other variables which would enhance our understanding of causal relationships. Reputation has been treated by some authors as one of the most reliable cues of the ability of a service company to satisfy customers' needs (Nguyen \& Leblanc, 2001) and „an essential anchor for the perception of satisfaction“ (Walsh et al., 2006, p. 414). This study could be further extended by encompassing customer satisfaction as a potential mediator between reputation and customer behavioural intentions, as a number of recent studies in diverse service settings, including retailing, reveal significant impact of satisfaction on customer behavioural intentions (Vesel \& Zabkar, 2009; Pantouvakis, 2013). In line with Gatzert's (2015) evidence of significant impact of corporate reputation on customer trust, and Rajić et al.'s (2016) findings of the antecedent role of trust to customer loyalty in the context of small and medium-sized enterprises, future studies would benefit from the examination of the mediating role of customer trust in the relationship between corporate reputation and customer loyalty. 
Rajić T. et al.: Antecedents and outcomes of retailer reputation: Evidence from an...

\section{Conclusions}

The thrust of this paper was to examine the antecedents and consequences of retailer reputation in the context of an emerging economy, taking into account customers' perspective. Findings of the study indicate direct relatedness of both service quality and perceived value to retailer reputation and the direct influence of retailer reputation on customer loyalty. In addition to reputation, results of the study indicate direct impact of perceived value to customer loyalty, whereas in the context of grocery retailing service quality emerged as an indirect determinant of customer loyalty. According to this study's findings, due attention should be paid to the behaviour of service personnel towards customers, retailer's communication with customers, store layout and assortment and ambience as these service quality dimensions positively impact perceived value and customers' perceptions of a retailer's reputation, which further contribute to customers' willingness to recommend the retailer to friends and relatives, speak highly of the retailer and purchase from the same retailer again.

\section{References}

Anderson, J.C., \& Gerbing, D.W. (1988). Structural equation modeling in practice: a review and recommended two-step approach. Psychological Bulletin, 411-423; 103

Asubonteng, P., McCleary, K.J., \& Swan, J.E. (1996). SERVQUAL revisited: A critical review of service quality. The Journal of Services Marketing, 62-81; 10.

Bartikowski, B., \& Walsh, G. (2011). Investigating mediators between corporate reputation and customer citizenship behaviors. Journal of Business Research, 39-44; 64.

Bartikowski, B., Walsh, G., \& Beatty, S.E. (2011). Culture and age as moderators in the corporate reputation and loyalty relationship. Journal of Business Research, 966-972; 64.

Brady, M.K., Knight, G.A., Cronin, J.J., Tomas, G., Hult, M., \& Keillor, B.D. (2005). Removing the contextual lens: a multinational, multi-setting comparison of service evaluation models. Journal of Retailing, 215-230; 81.

Buttle, F. (1996). SERVQUAL: review, critique, research agenda. European Journal of Marketing, 8-32; 30.

Caruana, A., Cohen, C., \& Krentler, K.A. (2005). Corporate reputation and shareholders' intentions: An attitudinal perspective. Brand Management, 429$440 ; 13$.

Caruana, A., \& Ewing, M.T. (2010). How corporate reputation, quality, and value influence online loyalty. Journal of Business Research, 1103-1110; 63.

Chen, C.F., \& Chen, F.S. (2010). Experience quality, perceived value, satisfaction and behavioral intentions for heritage tourists. Tourism Management, 29-35; 31. 
Rajić T. et al.: Antecedents and outcomes of retailer reputation: Evidence from an...

Chen, C.F., \& Cheng, L.T. (2012). A study on mobile phone service loyalty in Taiwan. Total Quality Management \& Business Excellence, 807-819; 23.

Churchill, , \& G.A.Jr., (1979). A Paradigm for Developing Better Measures of Marketing Constructs. Journal of Marketing Research, 64-73; 16.

Dabholkar, P.A., Thorpe, D.I., \& Rentz, J.O. (1996). A Measure of Service Quality for Retail Stores: Scale Development and Validation. Journal of the Academy of Marketing Science, 3-16; 24.

Dowling, G. (2006). How Good Corporate Reputations Create Corporate Value. Corporate Reputation Review, 134-143; 9.

Ewing, M.T., Windisch, L., \& Newton, F.J. (2010). Corporate reputation in the People's Republic of China: A B2B perspective. Industrial Marketing Management, 728736; 39.

Fernández-Gámez, M.A., Gil-Corral, A.M., \& Galán-Valdivieso, F. (2016). Corporate reputation and market value: Evidence with generalized regression neural networks. Expert Systems With Applications, 46, 69-76; DOI: 10.1016/j.eswa.2015.10.028.

Fombrun, C., Gardberg, N., \& Sever, J. (2000). The reputation quotientSM: A multistakeholder measure of corporate reputation. The Journal of Brand Management, 241-255; 7.

Fornell, C., \& Larcker, D.F. (1981). Evaluating Structural Equation Models with Unobservable Variables and Measurement Error. Journal of Marketing Research, 18, pp. 39-50.

Gatzert, N. (2015). The impact of corporate reputation and reputation damaging events on financial performance: Empirical evidence from the literature. European Management Journal, 33(6); 485-499; DOI: 10.1016/j.emj.2015.10.00.

Gotsi, M., \& Wilson, A.M. (2001). Corporate reputation: seeking a definition. Corporate Communications, nternational Journal, An I; 24-30; 6.

Graham, M.E., \& Bansal, P. (2007). Consumers' Willingness to Pay for Corporate Reputation: The Context of Airline Companies. Corporate Reputation Review, 189-200; 10.

Grubor, A., \& Milićević, N. (2016). Product availability from delivery aspect - evidence from retailers in selected Western Balkan countries. Industrija, 44 (2); 67-84; doi: 10.5937/industrija44-10035..

Hair, , J.F.Jr., , Black, W.C., Babin, B.J., \& Anderson, R.E. (2010). Multivariate Data Analysis, A Global Perspective. New Jersey: Pearson Prentice Hall, Upper Saddle River. 7th edn..

Helm, S. (2011). Employees' awareness of their impact on corporate reputation. Journal of Business Research, 657-663; 64.

Jarvinen, R., \& Suomi, K. (2011). Reputation attributes in retailing services: managerial perspective. Managing Service Quality, 410-423; 21.

Jöreskog, K.G., \& Sörbom, D. (1993). LISREL 8: User's Reference Guide. Chicago: Scientific Software International.

Keh, H.T., \& Xie, Y. (2009). Corporate reputation and customer behavioral intentions: The roles of trust, identification and commitment. Industrial Marketing Management, 732-742; 38.

Ko, E., Hwang, Y.K., \& Kim, E.Y. (2013). Green marketing' functions in building corporate image in the retail setting. Journal of Business Research, 1709-1715; 66. 
Rajić T. et al.: Antecedents and outcomes of retailer reputation: Evidence from an...

Kuo, Y.F., Wu, C.M., \& Deng, W.J. (2009). The relationships among service quality, perceived value, customer satisfaction, and post-purchase intention in mobile value added services. Computers in Human Behavior, 887-896; 25.

Martinelli, E., \& Balboni, B. (2012). Retail service quality as a key activator of grocery store loyalty. The Service Industries Journal, 2233-2247; 32.

Nadiri, H., \& Tümer, M. (2009). Retail service quality and behavioural intentions: an empirical application of the retail service quality scale in Northern Cyprus. $E+M$ Ekonomie A Management, 127-139; 2.

Nguyen, N., \& Leblanc, G. (2001). Corporate image and corporate reputation in customers' retention decisions in services. Journal of Retailing and Consumer Services, 227-236; 8.

Nunnally, J.C., \& Bernstein, I.H. (1994). Psychometric theory. New York: McGraw-Hill. 3rd ed.

Oliver, R.L. (1999). Whence Consumer Loyalty?. Journal of Marketing, 33-44; 63.

Page, G., \& Fearn, H. (2005). Corporate Reputation: What Do Consumers Really Care About?. Journal of Advertising Research, 305-313; 45.

Pan, Y., Sheng, S., \& Xie, F.T. (2012). Antecedents of customer loyalty: An empirical synthesis and reexamination. Journal of Retailing and Consumer Services, 150$158 ; 19$.

Pantouvakis, A. (2013). The moderating role of nationality on the satisfaction loyalty link: evidence from the tourism industry. Total Quality Management \& Business Excellence, DOI: 10.1080/14783363.2013.776758..

Parasuraman, A., Zeithaml, V., \& Berry, L. (1988). SERVQUAL: A Multiple-Item Scale for Measuring Consumer Perceptions of Service Quality. Journal of Retailing, 1240; 64.

Park, J.K., Gunn, F., \& Han, S.L. (2012). Multidimensional trust building in e-retailing: Cross-cultural differences in trust formation and implications for perceived risk. Journal of Retailing and Consumer Services, 304-312; 19.

Korda, P.A., Snoj, B., \& Zabkar, V. (2012). Antecedents and outcomes of perceived service value: Evidence from Slovenia. E+M Ekonomie a Management, 105-115; 15.

Rajic, T., \& Dado, J. (2013). Modelling the relationships among retail atmospherics, service quality, satisfaction and customer behavioural intentions in an emerging economy context. Total Quality Management \& Business Excellence,DOI: 10.1080/14783363.2013.776759.

Rajic, T., Dado, J., \& Taborecka-Petrovicova, J. (2013). Linking Retail Service Quality, Satisfaction and Perceived Value to Customer Behavioral Intentions: Evidence from Serbia. E+M Ekonomie a Management, 99-112; 16.

Rajić, T., Nikolić, I., \& Milošević, I. (2016). The Antecedents of SMEs' Customer Loyalty: Examining the role of Service Quality, Satisfaction and Trust. Industrija, 44(3); 97-114; doi: 10.5937/industrija44-10741..

Ruiz, D.M., Gremler, D.D., Washburn, J.H., \& Carrión, G.C. (2008). Service value revisited: Specifying a higher-order, formative measure. Journal of Business Research, 1278-1291; 61.

Sarstedt, M., Wilczynski, P., \& Melewar, T.C. (2012). Measuring reputation in global markets: A comparison of reputation measures' convergent and criterion validities. In Journal of World Business. In Press; 10.1016/j.jwb.2012.07.017.. 
Rajić T. et al.: Antecedents and outcomes of retailer reputation: Evidence from an...

Setó-Pamies, D. (2012). Customer loyalty to service providers: examining the role of service quality, customer satisfaction and trust. Total Quality Management \& Business Excellence, 1257-1271; 23.

Walker, K. (2010). A Systematic Review of the Corporate Reputation Literature: Definition, Measurement, and Theory. Corporate Reputation Review, 357-387; 12.

Walsh, G., \& Beatty, S.E. (2007). Customer-based corporate reputation of a service firm: scale development and validation. Journal of the Academy of Marketing Science, 127-143; 35.

Walsh, G., Dinnie, K., \& Wiedmann, K.P. (2006). How do corporate reputation and customer satisfaction impact customer defection? A study of private energy customers in Germany. Journal of Services Marketing, 412-420; 20.

Wang, D.(., Yu, T.(., \& Chiang, (. (2016). Exploring the value relevance of corporate reputation: A fuzzy-set qualitative comparative analysis. Journal of Business Research, 69(4); 1329-1332; DOI: 10.1016/j.jbusres.2015.10.101.

Woodruff, R. (1997). Customer value: the next source for competitive advantage. Journal of the Academy of Marketing Science, 139-153; 25.

Vesel, P., \& Zabkar, V. (2009). Managing customer loyalty through the mediating role of satisfaction in the DIY retail loyalty program. Journal of Retailing and Consumer Services, 396-406; 16.

Vesel, P., \& Zabkar, V. (2010). Relationship quality evaluation in retailers' relationships with consumers. European Journal of Marketing, 1334-1365; 44.

Vuković, A., Mihić, S., Miletić, (., \& Čurčić, R. (2016). Corporate Social Responsibility as a part of Corporate Public Relations in Serbia. Industrija, 44(4); 159-173; doi: 10.5937/industrija44-12689..

Zeithaml, V.A. (1988). Consumer perceptions of price, quality, and value: a means-end model and synthesis of evidence. Journal of Marketing, 2-22; 52.

Zeithaml, V.A., Berry, L.L., \& Parasuraman, A. (1996). The Behavioral Consequences of Service Quality. Journal of Marketing, 31-46; 60.

Žabkar, V., Makovec, B.M., \& Dmitrović, T. (2010). Modelling perceived quality, visitor satisfaction and behavioural intentions at the destination level. Tourism Management, 537-546; 31. 
Rajić T. et al.: Antecedents and outcomes of retailer reputation: Evidence from an...

\section{Appendix}

Rotated component matrix

\begin{tabular}{|c|c|c|c|c|}
\hline \multirow[t]{2}{*}{ Items } & \multicolumn{4}{|c|}{ Factor loadings } \\
\hline & $\mathrm{F} 1$ & $\mathrm{~F} 2$ & F3 & F4 \\
\hline Factor 1 Service personnel & $(.873)$ & & & \\
\hline $\begin{array}{l}\text { I1 Employees at checkout counters perform their } \\
\text { tasks quickly and properly }\end{array}$ & .743 & & & \\
\hline $\begin{array}{l}\text { I2 Employees always have time to respond to } \\
\text { customers' enquiries }\end{array}$ & .759 & & & \\
\hline $\begin{array}{l}\text { I3 Employees are always curteous with customers } \\
\text { 14 Customers are served promptly and efficiently }\end{array}$ & $\begin{array}{l}.704 \\
.638\end{array}$ & & & \\
\hline $\begin{array}{l}\text { I5 Employees are willing to do more than asked for } \\
\text { to provide quality service }\end{array}$ & .688 & & & \\
\hline $\begin{array}{l}\text { I6 Employees give special treatment to regular } \\
\text { customers }\end{array}$ & .647 & & & \\
\hline $\begin{array}{l}\text { I7 Employees have the knowledge to answer } \\
\text { customers' questions }\end{array}$ & .619 & & & \\
\hline $\begin{array}{l}\text { I } 8 \text { Employees' behaviour instill confidence in } \\
\text { customers }\end{array}$ & .634 & & & \\
\hline Factor 2 Communication & & $(.822)$ & & \\
\hline $\begin{array}{l}19 \text { This retailer informs customers about special } \\
\text { offers }\end{array}$ & & .794 & & \\
\hline $\begin{array}{l}\text { I10 Promotional materials associated with this } \\
\text { retailer (fliers, leaflets, brochures) are visually } \\
\text { appealing }\end{array}$ & & .777 & & \\
\hline $\begin{array}{l}\text { I11 This retailer offers attractive sales promotion } \\
\text { activities (coupons, free samples, price reductions) }\end{array}$ & & .764 & & \\
\hline $\begin{array}{l}\text { I12 This retailer has attractive and modern-looking } \\
\text { equipment }\end{array}$ & & .629 & & \\
\hline Factor 3 Store layout \& assortment & & & $(.752)$ & \\
\hline $\begin{array}{l}\text { I13 Store layout makes it easy for customer to move } \\
\text { around }\end{array}$ & & & .685 & \\
\hline $\begin{array}{l}\text { I14 Store layout makes it easy for customers to find } \\
\text { what they look for }\end{array}$ & & & .710 & \\
\hline $\begin{array}{l}\text { I15 This retailer's assortment allows one-stop } \\
\text { shopping }\end{array}$ & & & .580 & \\
\hline I16 This retailer offers wide and deep assortment & & & .658 & \\
\hline Factor 4 Ambience & & & & $(.810)$ \\
\hline I17 Pleasant temperature in the store & & & & .787 \\
\hline I18 Pleasant combination of colors & & & & .710 \\
\hline I19 Pleasant lighting in the store & & & & .678 \\
\hline I20 Pleasant scents in the store & & & & .720 \\
\hline Eigenvalue & 4.030 & 2.914 & 2.698 & 2.631 \\
\hline$\%$ of variance & 20.149 & 14.571 & 13.490 & 13.156 \\
\hline Cummulative $\%$ of variance & 20.149 & 34.720 & 48.210 & 61.366 \\
\hline
\end{tabular}

Note: Numbers within brackets are Cronbach's alpha factors of the dimensions of retail service quality

Source: authors' calculations 